\title{
Urea Amendment Alleviated Morphological and Physiological Damages and Yield Loss of Winter Wheat Subjected to Cold Stress at Jointing Stage
}

\author{
Chunyan Li ( $\square$ licy@yzu.edu.cn ) \\ Yangzhou University \\ Jing Yang \\ Yangzhou University \\ Min Zhu \\ Yangzhou University \\ Jinfeng Ding \\ Yangzhou University \\ Xinkai Zhu \\ Yangzhou University \\ Guisheng Zhou \\ Yangzhou University \\ Wenshan Guo \\ Yangzhou University
}

\section{Research Article}

Keywords: cold stress, wheat, yield, morphology, physiology

Posted Date: March 7th, 2022

DOI: https://doi.org/10.21203/rs.3.rs-1332108/v1

License: (c) (i) This work is licensed under a Creative Commons Attribution 4.0 International License. Read Full License 


\section{Abstract}

Cold stress in spring is an abiotic stress limiting the growth and productivity of winter wheat. A controlled pot experiment was done to explore the possibility of applying urea to alleviate the low temperature $\left(3^{\circ} \mathrm{C} /-4^{\circ} \mathrm{C}\right.$, day/night)damage to wheat cultivar Yangmai 16 at jointing stage. Urea at different rates was applied at the 5 th day after cold stress. Cold stress decreased grain yield and plant height. Compared with the unstressed control, the content of soluble sugar, proline, zeatin riboside (ZR), and abscisic acid ( $A B A$ ) in the leaves was increased under longer cold stress. These above parameters in the stressed treatments without urea amendment were higher than those with urea amendment on the 10th day. The change in $\mathrm{GA}_{3}$ concentration was opposite to the concentrations of ABA and ZR. The decline in the concentrations of osmotic adjustment substances, balanced hormone concentrations, and increased grain number per ear and ear number were the main reasons for the increased grain yield after urea application. Remedial effects was enhanced with the higher urea remedial level under the same cold stress duration. Our study suggested that suitable urea remedial rates are recommended based on the freezing index in wheat to alleviate the impacts of low temperature on wheat production at jointing stage.

\section{Introduction}

Global warming is not only increasing average global temperature but also dramatically increasing the frequency and strength of severe cold days. The increasing occurrence of severe cold weather has become a restricting factor limiting crop production in many parts of the world (Neilson et al. 2010; FAO 2020). As one of the most important staple crops with wide global distribution, winter wheat is prone to severe cold injury during the growth stages, including germination, jointing, booting, and flowering (Fuller et al. 2007; Frederiks et al. 2015; Li et al. 2016; Ji et al. 2017; Flores et al. 2021).

China is one of the largest winter wheat producers in the world. However, low temperature stress has become a general issue for winter wheat growth during winter and early spring seasons, especially in the Huanghuai region and the middle and lower reaches of the Yangtze River. These areas include Henan, Shandong, Hebei, Anhui, and Jiangsu, which are the major wheat production provinces in China. Over the past decades, severe losses in wheat production have occurred due to low temperature. In Henan Province and Shandong Province, severe frost occurs frequently, with an occurrence frequency exceeding $30 \%$. Alone in Henan Province, the occurrence frequency of frost stress on winter wheat has reached more than $50 \%$ in a 50-year period from 1964 to 2014 (Zhu et al. 2018). The wheat area suffering from frost injury was about 26.7 million ha in Henan Province in the 2004-2005 wheat season and about annual mean 0.22-0.45 million ha in Anhui Province over the 1986-2017 wheat seasons (Luo et al. 2011; Chen et al. 2020).

Low temperature in spring often has negative effects on wheat grain yield formation. In Henan province, wheat yield decreased by $19.9 \%$ when low temperature happened at jointing stage and reduced by $8.9 \%$ when low temperature happened at booting stage (Gao et al. 2015). It was reported that 3.1-56.4\% yield reduction was recorded for two wheat cultivars treated with low-temperature at jointing stage (Ji et al. 2017). Therefore, freezing injury occurred in spring significantly limits the growth and yield of winter wheat.

The wheat plants under low temperature may undergo a series of morphological and physiological changes, which consequently inhibit plant growth and yield development. Limin and Fowler (2000) reported that low temperature markedly decreased carbohydrate production and accumulation. Low temperature stress also induced the overproduction of reactive oxygen species (ROS) such as hydrogen peroxide $\left(\mathrm{H}_{2} \mathrm{O}_{2}\right)$, superoxide radical, and singlet oxygen as well as hydroxyl radical (Alscher et al. 1997; Dai et al. 2009; Yu et al. 2020). Improved activity of guaiacol peroxidase and catalase can remove excess $\mathrm{H}_{2} \mathrm{O}_{2}$ (Horvath et al. 2007; Yang et al. 2013; Valitovaa et al. 2019). Low temperature stress resulted in changes in proline content, sugar composition and accumulation, as well as hormonal levels and balance. Li et al. (2015) observed that proline and sugar were associated with typical stress responses and the overproduction of proline and sugar enhanced cold tolerance (Patton et al. 2007; Dörffling et al. 2009; Majláth et al. 2012). 
Low temperature also caused the changes in endogenous hormones in plants (Penfield 2008). It has been reported that auxin participates in stress responses and functions by up-regulating or down-regulating a group of primary responsive genes to some extent (Majláth et al. 2012; Kalapos et al. 2016). Changes in the levels of hormones in wheat, such as cytokinins (CKs), indole-3-acetic acid (IAA), and nitric oxide, illustrate that wheat plants attempt to maintain growth during cold stress (Majláth et al. 2012; Yu. et al. 2020). Different strategies have been developed to combat the damages caused by low temperature stresses in wheat production ( $\mathrm{Li}$ et al. 2013; Hussain et al. 2018). Nitrogen application is one of feasible remedial practices. But there is little information on the application of nitrogen on winter wheat after low temperature stress. We hypothesized that nitrogen amendment might be a feasible way to alleviate and combat the inhibitive effects of low temperature stress on winter wheat at jointing stage.

Therefore, the objectives of this study were to (1) illustrate the effects of low temperature at jointing stage on the yield and morphological attributes in winter wheat, (2) investigate the physiological responses of urea amendment following lowtemperature stress on winter wheat growth recovery and yield loss alleviation, and (3) determine suitable nitrogen rates for alleviating low temperature stress at jointing stage.

\section{Materials And Methods}

A controlled pot experiment was done on Experimental Farm of Yangzhou University $\left(119.42^{\circ} \mathrm{E}, 32.39^{\circ} \mathrm{N}\right)$, Jiangsu Province, China, in the two winter wheat growing seasons of 2012-2013 and 2013-2014. Yangmai 16, a widely extended winter wheat cultivar in the middle and lower reaches of the Yangtze River, was used.

\subsection{Preparation of wheat plants}

The wheat seedlings were developed in pots and transported to a phytotron for low temperature treatment. The pots were $0.28 \mathrm{~m}$ in diameter at the top, $0.22 \mathrm{~m}$ in diameter at the bottom, and $0.30 \mathrm{~m}$ in height. Each pot was filled with $13.0 \mathrm{~kg}$ sandy loam from a wheat field nearby. Soil containing $100.01 \mathrm{mg} \mathrm{kg}^{-1}$ available $\mathrm{N}, 50.11 \mathrm{mg} \mathrm{kg}^{-1}$ available $\mathrm{P}$, and 149.08 mg kg-1 available $\mathrm{K}$ in 2012 and $98.71 \mathrm{mg} \mathrm{kg}^{-1}$ available $\mathrm{N}, 44.62 \mathrm{mg} \mathrm{kg}^{-1}$ available $\mathrm{P}$, and $156.83 \mathrm{mg} \mathrm{kg}^{-1}$ available K in 2013.

For each pot, 12 seeds were sown at a seeding depth of $2.0 \mathrm{~cm}$ on October 31, 2012 and November 2, 2013, respectively. During the wheat growth period, $1.75 \mathrm{~g} \mathrm{~N}, 1.05 \mathrm{~g} \mathrm{P}_{2} \mathrm{O}_{5}$, and $1.05 \mathrm{~g} \mathrm{~K}_{2} \mathrm{O}$ were applied for each pot, half of which was applied before sowing and half at jointing stage. At the 4th leaf stage, all the pots were thinned to 6 plants per pot. During the growth period, the pots were irrigated regularly to maintain a good moisture level and avoid water deficit. Other management practices were followed in accordance with local recommendations. At jointing stage, the plants were ready for low temperature treatment and urea amendment.

\subsection{Low temperature treatment}

A temperature-controlled phytotron was used in this study. It was set at $3^{\circ} \mathrm{C} /-4^{\circ} \mathrm{C}$ (day/night), relative humidity $70 \%( \pm 1 \%)$, $12 \mathrm{~h}$ photoperiod between 6:00 and 18:00, and photosynthetic photon flux density $900.0 \mu \mathrm{mol} \mathrm{m}^{-2} \mathrm{~s}^{-1}$.

In the 2012-2013 wheat growing season, the plants were treated for $24 \mathrm{~h}$ and $48 \mathrm{~h}$ (referred to as T24 and T48 hereinafter). In the 2013-2014 wheat growing season, the plants were treated for $24 \mathrm{~h}, 48 \mathrm{~h}$, and $72 \mathrm{~h}$ (referred to as T24, T48, and T72 hereinafter).

\subsection{Urea amendment}

Urea (N 46\%) was applied on the fifth day after the low temperature treatment was finished. The amount of urea per pot was calculated based on the soil weight of the tillage layer in a nearby field where the soil in the pots were collected. The weight of tillage layer soil of the field is about 2.25 million $\mathrm{kg} \mathrm{hm}^{-2}$. In the 2012-2013 wheat growing season, urea was 
applied at $0,0.9$, and $1.3 \mathrm{~g} \mathrm{pot}^{-1}$, which was approximately equivalent to 0,150 , and $225 \mathrm{~kg} \mathrm{~N} \mathrm{ha}^{-1}$ (referred to as N0, N150, and N225 hereinafter). In the 2013-2014 wheat growing season, urea was applied at 0, 0.6, 0.9, and 1.3 g pot ${ }^{-1}$, which was approximately equivalent to $0,105,150$, and $225 \mathrm{~kg} \mathrm{~N} \mathrm{ha}^{-1}$ (referred to as N0, N105, N150, and N225 hereinafter). To promote the nitrogen uptake of wheat plants, urea was dissolved with $500 \mathrm{~mL}$ water and applied onto the soil surface of the pots.

In this study, a control growing in natural environment (without low temperature stress and urea amendment) was used. The study was arranged in a single factorial design with 8 replicates (each pot as a replicate). Thus, there were 7 and 13 treatments, respectively, in the 2012-2013 and 2013-2014 wheat growing seasons.

\subsection{Observations and measurements}

\subsubsection{Grade and proportion of freezing injury investigation}

The cold symptoms appeared on the fifth day after low-temperature treatment. We investigated the degree and proportion of freezing injury depending on the freezing injury standards used in wheat variety regional experiments in China and divided the freezing damage into five grades (Miao et al. 2007). Grade 1 was the lowest and indicated no freezing injury. Etiolation of one-third of the leaf tip corresponded to grade 2. One-third to one-half of the leaf tip being injured by freezing was grade 3 . Withered and shed leaves were grade 4 . Death of the main stems and tillers of wheat corresponded to grade 5 .

\subsubsection{Osmotic adjustment substances}

The second fully-expanded leaves from the top of the plant on the 10th day after urea amendment and from the colddamaged wheat plants at jointing stage were used to determine the osmotic adjustment and hormonal content.

Proline content was measured according to Zhang and Qu (2003). Wheat leaves were extracted with 3.0\% sulfosalicylic acid, incubated in a boiling water bath for $15 \mathrm{~min}$, and then separated with filter paper. The reaction mixture containing 2 $\mathrm{mL}$ extract, $3.0 \mathrm{~mL}$ ninhydrin solution, and $2.0 \mathrm{~mL}$ acetic acid was incubated for $40 \mathrm{~min}$ at $100^{\circ} \mathrm{C}$. The proline content was determined by monitoring the absorbance at $520 \mathrm{~nm}$.

Soluble sugar content was measured according to Zhang and Qu (2003). Leaves were extracted with 80\% ethanol, placed in a conical flask for $1 \mathrm{~h}$, and then filtered with filter paper. The assay medium containing $0.5 \mathrm{~mL}$ extract, $4 \mathrm{~mL}$ anthrone (100 mL 72\% $\mathrm{H}_{2} \mathrm{SO}_{4}+200 \mathrm{mg}$ anthrone), and $1.5 \mathrm{~mL}$ distilled water was incubated for $15 \mathrm{~min}$ at $100^{\circ} \mathrm{C}$, and then the absorbance was assessed at $620 \mathrm{~nm}$.

\subsubsection{Hormone contents}

The content of abscisic acid (ABA), zeatin riboside (ZR), and gibberellic acid $\left(\mathrm{GA}_{3}\right)$ was measured by two-dimensional high-performance liquid chromatography (HPLC) following the method of Dobrev et al. (2005). Leaves were extracted and purified by immunoaffinity chromatography and quantified according to Pěnčík et al. (2009). The supernatant was separated using an Acquity ultra-high performance (UP) LC system (Waters 2695, U.S.A. ) equipped with a Symmetry $\mathrm{C}_{18}$ column ( $5 \mu \mathrm{m}, 4.6 \mathrm{~mm} \times 250 \mathrm{~mm}$; Waters, U.S.A.). Methanol, 0.6\% acetic acid, and acetonitrile (10: 9: 1 in volume) was used as a mobile phase, and its flow rate was $1.0 \mathrm{~mL} \mathrm{~min}^{-1}$. Pure $A B A, G_{3}$, and $Z R$ were used as the standards.

\subsubsection{Freezing injury grade proportion, freezing injury index, yield restoration effect, and nitrogen partial factor productivity}

The freezing injury grade proportion, freezing injury index, yield restoration effect, and nitrogen partial factor productivity were calculated as follows: 
The freezing injury grade proportion $(\%)=$ the number tillers at each freezing injury grade/total tillers $\times 100$

Freezing injury index $=\left(\sum\right.$ freezing injury grade $(\geq$ grade 2$) \times$ proportion of freezing injury at the corresponding injury grade) $/ 5$

Yield restoration effect $(\%)=$ (yield with remedial fertilizer - yield without remedial fertilizer) / yield without remedial fertilizer $\times 100$

Nitrogen partial factor productivity $\left(\mathrm{g} \mathrm{g}^{-1}\right)=$ yield / total nitrogen amount

\subsubsection{Yield assessment}

At maturity, wheat plants from 8 pots in each treatment were harvested, and the grain yield per pot was assessed. The grain yield was adjusted to $13 \%$ moisture content.

\subsection{Statistical analysis}

The study was arranged in a single factorial design, with 7 and 13 treatments and 8 replicates (each pot as a replicate), respectively, in the 2012-2013 and 2013-2014 wheat growing seasons. For statistical analysis, analysis of variance (ANOVA) was performed $(P<0.05)$ using DPS 7.05 Statistical Software (DPS, Zhejiang, China) to assess the effects of the treatments.

Unless specifically stated, the following result section focused on the 2013 to 2014 wheat growing season due to the fact that there were more low temperature treatments and urea rates in this growing season.

\section{Results}

\subsection{Freezing injury grade after low-temperature stress at jointing stage}

The freezing injury grade, proportion, and index in the wheat plants increased with longer low-temperature duration in the both growing seasons. As shown in Table 1,55\% of wheat plants were injured at different degrees when treated at $3^{\circ} \mathrm{C} /$ $-4^{\circ} \mathrm{C}$ for $24 \mathrm{~h}$ (T24). The fifth level grade (main stems and tillers dead) was $2.5 \%$ under T24 and increased by $11.3 \%$ under T48 in the 2012-2013 wheat growing season. The average freezing injury index was $0.35,0.50$, and 0.66 under T24, T48, and T72, respectively, in the two wheat growing seasons, indicating that Yangmai 16 was sensitive to low temperatures at jointing stage. 
Table 1

Degree and proportion of freezing injury of wheat plants under low temperature stress at jointing stage

\begin{tabular}{|c|c|c|c|c|c|c|c|}
\hline \multirow[t]{2}{*}{ Year } & \multirow{2}{*}{$\begin{array}{l}\text { Time } \\
\text { (h) }\end{array}$} & \multicolumn{5}{|c|}{ Grade of freezing injury and proportion (\%) } & \multirow{2}{*}{$\begin{array}{l}\text { Freezing } \\
\text { injury index }\end{array}$} \\
\hline & & 1 & 2 & 3 & 4 & 5 & \\
\hline \multirow[t]{3}{*}{$2012-2013$} & 24 (T24) & $45.34 b$ & $14.64 a$ & $21.68 \mathrm{~b}$ & $15.89 b$ & $2.45 b$ & 0.34 \\
\hline & 48 (T48) & $27.54 \mathrm{c}$ & $10.42 b$ & $28.65 a$ & $22.06 a$ & $11.33 a$ & 0.50 \\
\hline & Control & $100.00 \mathrm{a}$ & $0.00 c$ & $0.00 c$ & $0.00 c$ & $0.00 c$ & - \\
\hline \multirow[t]{4}{*}{ 2013-2014 } & 24 (T24) & $42.83 b$ & $13.12 \mathrm{a}$ & $26.53 b$ & $13.85 \mathrm{c}$ & $3.67 c$ & 0.36 \\
\hline & 48 (T48) & $25.27 c$ & $11.46 \mathrm{~b}$ & $32.23 a$ & $21.65 b$ & $9.39 b$ & 0.51 \\
\hline & 72 (T72) & $12.06 \mathrm{~d}$ & $8.66 c$ & $24.75 b$ & $34.25 a$ & $20.28 a$ & 0.66 \\
\hline & Control & $100.00 a$ & $0.00 d$ & $0.00 c$ & $0.00 d$ & $0.00 d$ & - \\
\hline
\end{tabular}

* Different small letters in the same column meant significant difference among treatments for the same year at the 0.05 level.

\subsection{Effect of fertilizer amendment on plant morphology}

Plant height ranged from $67.60 \mathrm{~cm}$ to $63.38 \mathrm{~cm}$ after low-temperature stress of $72 \mathrm{~h}$ at jointing stage, while the plant height of the control treatment was $87.27 \mathrm{~cm}$ (Fig. 1). The plant height was decreased by 22.5-27.4\%. Plant height increased to $83.46 \mathrm{~cm}$ under T24N225 treatment, increased by $23.5 \%$ as compared with the cold treatment without the urea amendment. Plant height was $75.24 \mathrm{~cm}$ under T72N225 treatment, but dropped by $13.8 \%$ as compared with the plant in the natural environment. Remedial fertilizer after cold stress at jointing stage mainly promoted the length of the two upper internodes, which recovered the ear length and plant height to some extent. The stronger the cold stress was, the more significant the retrieval effects of remedial urea on plant height were.

\subsection{Effect of fertilizer amendment after cold stress on yield formation}

Grain yield exhibited a decreasing trend with increased low temperature duration (Table 2). Compared with the control, a $54.1-65.3 \%$ decrease in yield was observed under low temperature stress at jointing stage. The ear number was decreased from 34.3-38.1\% with longer low-temperature stress in the 2013-2014 wheat growing season. Fertilizer amendment improved the ear number with increased urea application after cold stress of the same cold duration. The grain number per spike was significantly reduced with increased cold duration stress. The grain number per spike was increased by $9.3 \%$ under T24N225, compared with the treatment T24N0, while it was lower than that in the natural environment even though more remedial fertilizer had been applied. The 1000-grain weight was decreased with increased cold duration. In the same stress treatment, the yield restoration was the highest under the treatment with $225 \mathrm{~kg} \mathrm{ha}^{-1}$ urea amendment. The yield was restored by 33.9\% under T24N225, 44.8\% under T48N225, and 58.6\% under T72N225 in the 2013-2014 wheat growing season. Their relative effects of yield restoration were also the highest among the different urea amendment levels. 
Table 2

Effects of remedial fertilizer after low temperature stress on wheat yield formation

\begin{tabular}{|c|c|c|c|c|c|c|c|c|c|}
\hline \multirow[t]{2}{*}{ Year } & \multirow{2}{*}{$\begin{array}{l}\text { Time } \\
\text { (h) }\end{array}$} & \multirow[t]{2}{*}{$\begin{array}{l}\text { Freezing } \\
\text { injury } \\
\text { index }\end{array}$} & \multirow{2}{*}{$\begin{array}{l}\text { Remedial } \\
\text { urea rate }\end{array}$} & \multirow[t]{2}{*}{$\begin{array}{l}\text { Ear per } \\
\text { pot }\end{array}$} & \multirow{2}{*}{$\begin{array}{l}\text { Grain } \\
\text { number } \\
\text { per } \\
\text { spike }\end{array}$} & \multirow{2}{*}{ 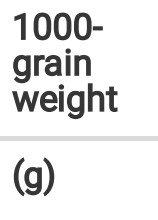 } & \multirow{2}{*}{$\begin{array}{l}\text { Actual } \\
\text { yield } \\
\text { per pot } \\
\text { (g) }\end{array}$} & \multirow{2}{*}{$\begin{array}{l}\text { Yield } \\
\text { restoration } \\
\text { effect }( \pm \\
\%)\end{array}$} & \multirow{2}{*}{$\begin{array}{l}\text { Partial } \\
\text { factor } \\
\text { productivity }\end{array}$} \\
\hline & & & & & & & & & \\
\hline \multirow{7}{*}{$\begin{array}{l}2012- \\
2013\end{array}$} & 24(T24) & 0.34 & 0 (N0) & $24.00 d^{*}$ & $36.52 c$ & 42.57ab & $37.01 \mathrm{e}$ & - & 21.15 \\
\hline & & & $\begin{array}{l}150 \\
\text { (N150) }\end{array}$ & $28.5 c$ & $42.28 b$ & $44.54 a$ & $52.43 b$ & 41.66 & 24.23 \\
\hline & & & $\begin{array}{l}225 \\
\text { (N225) }\end{array}$ & $29.67 b c$ & $42.50 \mathrm{~b}$ & $44.83 a$ & $54.78 b$ & 48.01 & 23.11 \\
\hline & 48(T48) & 0.5 & 0 (N0) & $22.00 \mathrm{e}$ & $33.73 f$ & $38.51 \mathrm{c}$ & $28.31 f$ & - & 16.18 \\
\hline & & & $\begin{array}{l}150 \\
(N 150)\end{array}$ & $29.5 b c$ & $36.98 c$ & 41.77ac & $43.25 d$ & 52.77 & 19.99 \\
\hline & & & $\begin{array}{l}225 \\
\text { (N225) }\end{array}$ & $30.67 b$ & $37.69 c$ & 42.57ab & $48.92 c$ & 72.8 & 20.64 \\
\hline & Control & - & & $32.50 \mathrm{a}$ & $52.63 a$ & $44.17 a$ & $73.17 a$ & - & 41.81 \\
\hline \multirow{12}{*}{$\begin{array}{l}2013- \\
2014\end{array}$} & 24(T24) & 0.36 & 0 (N0) & 23.00de & $37.65 b f$ & $44.26 a c$ & $36.69 \mathrm{ef}$ & - & 20.97 \\
\hline & & & $\begin{array}{l}105 \\
\text { (N105) }\end{array}$ & $25.67 \mathrm{~cd}$ & $39.93 \mathrm{bd}$ & $45.85 a b$ & $45.19 b c$ & 23.17 & 22.16 \\
\hline & & & $\begin{array}{l}150 \\
(N 150)\end{array}$ & $26.00 \mathrm{bd}$ & $40.07 \mathrm{bd}$ & 46.35ab & $46.87 b c$ & 27.75 & 21.66 \\
\hline & & & $\begin{array}{l}225 \\
\text { (N225) }\end{array}$ & $26.33 \mathrm{bd}$ & $41.15 b$ & $46.95 a$ & $49.13 b$ & 33.91 & 20.72 \\
\hline & 48(T48) & 0.51 & 0 (N0) & $23.00 \mathrm{de}$ & $36.75 \mathrm{dg}$ & $40.69 \mathrm{~cd}$ & $32.31 \mathrm{fg}$ & - & 18.46 \\
\hline & & & $\begin{array}{l}105 \\
\text { (N105) }\end{array}$ & $26.33 \mathrm{bd}$ & 39.00be & $42.11 \mathrm{bd}$ & 41.86ce & 29.56 & 20.52 \\
\hline & & & $\begin{array}{l}150 \\
(N 150)\end{array}$ & $26.33 \mathrm{bd}$ & $39.93 \mathrm{bd}$ & 42.9ad & $44.99 b c$ & 39.24 & 20.79 \\
\hline & & & $\begin{array}{l}225 \\
\text { (N225) }\end{array}$ & $27.5 b c$ & $40.83 b c$ & 42.74ad & $46.79 b c$ & 44.82 & 19.74 \\
\hline & 72(T72) & 0.66 & 0 (N0) & $21.67 e$ & $33.58 \mathrm{~g}$ & $38.71 d$ & $27.68 \mathrm{~g}$ & - & 15.82 \\
\hline & & & $\begin{array}{l}105 \\
\text { (N105) }\end{array}$ & $28.00 b c$ & $34.23 \mathrm{fg}$ & $39.31 d$ & $35.99 \mathrm{ef}$ & 30.02 & 17.65 \\
\hline & & & $\begin{array}{l}150 \\
\text { (N150) }\end{array}$ & $28.33 b c$ & $35.46 \mathrm{eg}$ & $40.51 \mathrm{~cd}$ & $38.47 \mathrm{df}$ & 38.98 & 17.78 \\
\hline & & & $\begin{array}{l}225 \\
\text { (N225) }\end{array}$ & $29.5 b$ & $36.86 \mathrm{cg}$ & $41.93 \mathrm{bd}$ & $43.89 \mathrm{bd}$ & 58.56 & 18.51 \\
\hline
\end{tabular}

* Values followed by the same letter in the same column for the same year are not significantly different $(P<0.05)$.

Table3 Correlation coefficients between the parameters on the 10th day after applying remedial fertilizer and plant height as well as yield 


\begin{tabular}{|c|c|c|c|c|c|c|c|c|c|}
\hline \multirow[t]{2}{*}{ Year } & Time & \multirow[t]{2}{*}{$\begin{array}{l}\text { Freezing } \\
\text { injury } \\
\text { index }\end{array}$} & \multirow{2}{*}{$\begin{array}{l}\text { Remedial } \\
\text { urea rate }\end{array}$} & \multirow[t]{2}{*}{$\begin{array}{l}\text { Ear per } \\
\text { pot }\end{array}$} & \multirow{2}{*}{$\begin{array}{l}\text { Grain } \\
\text { number } \\
\text { per } \\
\text { spike }\end{array}$} & \multirow{2}{*}{ 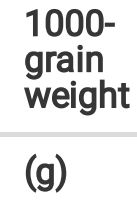 } & \multirow{2}{*}{$\begin{array}{l}\text { Actual } \\
\text { yield } \\
\text { per pot } \\
\text { (g) }\end{array}$} & \multirow{2}{*}{$\begin{array}{l}\text { Yield } \\
\text { restoration } \\
\text { effect ( } \pm \\
\%)\end{array}$} & $\begin{array}{l}\text { Partial } \\
\text { factor } \\
\text { productivity }\end{array}$ \\
\hline & (h) & & & & & & & & $\left(\mathrm{g} \mathrm{g}^{-1}\right)$ \\
\hline & Control & - & & $35.00 \mathrm{a}$ & $52.28 a$ & $44.5 \mathrm{ac}$ & $79.86 a$ & - & 45.63 \\
\hline
\end{tabular}

*Values followed by the same letter in the same column for the same year are not significantly different $(P<0.05)$.

Table3 Correlation coefficients between the parameters on the 10th day after applying remedial fertilizer and plant height as well as yield

At jointing stage, urea amendment mainly improved the grain yield by increasing the grain number per ear, with a path coefficient of $0.5258^{\star \star}(P<0.01)$, followed by ear number with a path coefficient of $0.4580^{\star *}(P<0.01)$. With increased urea application under the same treatment duration, the growth of wheat plants was restored better and the loss of grain yield lessened.

\subsection{Effect of remedial fertilizer on osmotic adjustment substance}

3.4.1 Soluble sugar Soluble sugar in the leaves on the 10th day after urea amendment to the cold-damaged plants under T24, T48, and T72 was lower than that of the cold-damaged plants without fertilizer amendment treatment (Fig. 2A). Compared with the control, the treatment T24 with urea amendment had a higher soluble sugar concentration in the leaf on the 10th day after urea amendment. The differences in soluble sugars of the leaves between the treatments and control significantly narrowed after applying three urea levels under T24. The soluble sugar concentration was decreased from 127.36-71.74\% on the 10th day after application of $150 \mathrm{~kg} \mathrm{ha}^{-1}$ and $225 \mathrm{~kg} \mathrm{ha}^{-1}$ urea under T24 compared with the control treatment (Fig. 2B). The soluble sugar concentration of the leaves on the 10th day under T72N225 treatment was lower than that of the treatment T72N0, with a decrease of $34.2 \%$, implying that the cold-damaged wheat plants recovered growth gradually after applying remedial fertilizer. We observed that remedial fertilization after low-temperature stress had more positive effects on reducing the concentration of soluble sugar in wheat plants. The recovering speed of severe cold stress treatment (T72) was slower than that of mild cold stress (T24).

3.4.2 Proline Compared with the treatment T24N0, the proline concentration in the second fully-expanded leaves on the 10th day after urea amendment was decreased from 5\% to16\% with the increased remedial urea rate under T24 (Fig. 2C, D). Under T48N225, the proline concentration was lower than that of T48N0, with a decrease by $13.0 \%$ on the 10 th day. The changes in proline concentration under T72 exhibited the same trend as under T24 with remedial fertilizer at three levels. All the treatments under T72 with nitrogen amendment had the highest proline concentration among all cold stress treatments, indicating that the recovery effect of nitrogen amendment on T72 was worse than those of T24 and T48. Similar to soluble sugar, the differences in the proline concentration in the leaves between treatments with urea amendment and the control narrowed on the 10th day after remedial urea application under three low-temperature duration levels.

\subsection{Effect of fertilizer amendment on hormone concentrations in the second expanded leaf from the top}

3.5.1 ABA Compared with the control, the ABA concentration in the second upper leaves on the 10th day of the treatment without fertilizer application gradually increased with the duration of treatment time after low-temperature stress (Fig. 3A). Within the same duration, the concentration of ABA was decreased gradually with the increased rate of fertilization. Under T48 and T72, compared with the control treatment, the ABA concentration under $225 \mathrm{~kg} \mathrm{ha}^{-1}$ urea amendment was significantly increased by $87.6 \%$ and $120.2 \%$ on the 10 th day. 
3.5.2 ZR Compared with the treatment without urea amendment, the ZR concentration decreased following urea amendment (Fig. 3B). Under T24N225, the ZR concentration was significantly lower by $16.9 \%$ than that of T24N0 on the 10 th day. The ZR concentration increased gradually with the increased treatment duration. Under the same lowtemperature duration, the ZR concentration dropped with increased fertilizer amount.

3.5.3 $\mathrm{GA}_{3}$ Compared with the control, the $\mathrm{GA}_{3}$ concentration decreased following low temperature stress (Fig. $3 \mathrm{C}$ ). Under the treatment of $\mathrm{T} 24, \mathrm{~T} 48$, and $\mathrm{T} 72$, the $\mathrm{GA}_{3}$ concentrations with $225 \mathrm{~kg} \mathrm{ha}^{-1}$ urea amendment was $54.6 \%, 63.5 \%$, and $69.8 \%$ lower than that of the control treatment on the 10th day. The $\mathrm{GA}_{3}$ concentration increased after urea application. The effect of increased urea application after low-temperature stress on recovering $\mathrm{GA}_{3}$ concentration was more obvious.

\subsection{Relationship between mechanism index and yield}

Proline, soluble sugar concentrations, $A B A$, and ZR concentrations in the 2 nd full expanded leaf from the top on the 10 th day after remedial urea application were negatively correlated, while the $\mathrm{GA}_{3}$ concentration was positively correlated with the length of the upper internode IV, internode V, plant height, and yield (Table 3). The higher proline, ABA, and ZR concentrations in the leaves under cold stress affected plant growth, resulting in shorter upper internode lengths, which influenced wheat yield formation.

\section{Discussion}

\subsection{Response of osmotic adjustments to remedial fertilizer after low temperature stress at jointing stage}

Carbohydrates play a crucial role in freezing tolerance (Livingston et al. 2006). Simple sugars, such as trehalose, sucrose, and raffinose, are especially correlated with enhanced cold tolerance (Kaplan et al. 2006; Hassan et al. 2021). In this study, significant increases in soluble sugar concentration in wheat under treatment without fertilizer amendment were observed, especially under the treatment T72NO (Fig. 2A), indicating that wheat plants adapted to cold stress by increased soluble sugar concentration. Salicylic Acid-treated wheat enhanced total soluble sugar contents under low-temperature conditions (Wang et al. 2020). In our study, the concentration of soluble sugars were reduced from $13.2-20.6 \%$, from $14.7-24 \%$, and from $7-13.2 \%$ under T24, T48, and T72 with increased remedial fertilizer rate. These findings imply that remedial fertilizer after low temperature stress at jointing stage is an efficient way to increase sucrose inversion.

Another essential protective substance in the plant response to abiotic stress is proline. The level of proline was correlated with wheat low-temperature tolerance (Dörffling et al.2009). In the present study, proline accumulation was enhanced on the 10th day after low-temperature stress without remedial fertilizer compared with the control and increased dramatically by $88.6 \%$ under T24N0, 107\% under T48N0, and 130\% under T72NO (Fig. 2C, 2D). Proline may act as an osmolyte and function as a compatible ROS scavenger, protecting the plant from such oxidative stress. Its accumulation might balance the cell redox status and buffer the cytosolic pH (Majláth et al.2012). High concentrations of proline can increase tissue turgor, advance osmotic regulation, and enhance plant resistance to low temperature (Li et al. 2017). In this study, the proline concentration was reduced significantly with increased remedial fertilizer at the same low-temperature duration, which demonstrated that remedial urea might contribute to the balance of proline metabolism and the growth recovery of the wheat plants. In summary, the lower soluble sugar and proline concentrations in wheat were likely to result in osmoregulatory recovery after remedial urea application, which ultimately contributed to faster recovery and growth of wheat plants.

\subsection{Hormone changes of remedial fertilizer after low temperature stress at jointing stage}


Plant endogenous hormones, such as $\mathrm{ABA}, \mathrm{GA}$, and $\mathrm{CK}_{\mathrm{S}}$, function as signaling molecules and participate in cold resistance (Sun et al. 2009; Vaseva et al. 2009; Wang et al. 2018). Low temperature-induced ABA accumulation in winter wheat at booting stage altered the activity of enzymes related to sucrose metabolism, which led to sucrose synthesis and accumulation in the young ears, thus causing yield losses (Zhang et al. 2019). In this study, we also noticed that soluble sugar and $A B A$ concentrations were increased in abundance after low-temperature stress from $24 \mathrm{~h}$ to $72 \mathrm{~h}$ (Fig. 2A, 3A). Lower $\mathrm{GA}_{3}$ content and higher $\mathrm{ABA}$ content in the seeds after chilling injury was previously found to inhibit seed germination, while treating the seeds with $\mathrm{GA}_{3}$ could mitigate the low-temperature injury to seed germination (Hou 2003). In this study, the $\mathrm{GA}_{3}$ concentration changed conversely to the concentration of ABA not only after low temperature (Fig. 3C), but also after the remedial urea amendment. In addition, remedial urea significantly maintained lower levels of endogenous $\mathrm{ABA}$ and $\mathrm{ZR}$ and higher $\mathrm{GA}_{3}$ levels, which enhanced the wheat growth rate. These results are well in accordance with the observations of Yang et al. (2013), who reported that low-temperature conditioning alleviated injury in kiwifruit by promoting higher $\mathrm{ABA} / \mathrm{GA}_{3}$ ratios.

In the present study, the levels of ABA and ZR in the treatment without remedial fertilizer gradually increased with the longer low-temperature duration at jointing stage, which are typical responses of wheat to low-temperature stress (Fig. 3A, 3B). These results suggested that wheat changed the balance of these hormones to adapt to low-temperature stress. Remedial urea was conducive to alleviating the low-temperature damage to wheat and improving wheat growth via the reduced $A B A$ as well as $Z R$ and increased $\mathrm{GA}_{3}$ concentrations following low-temperature stress at jointing stage.

\subsection{Contribution of remedial fertilizer after freezing injury to plant morphology and grain yield}

The warming of global mean winter temperatures promotes wheat growth in the previous winter, enhancing cold vulnerability in the next spring (Li et al. 2016). Low temperature can remarkably reduce the rates of wheat growth and development, resulting in changes in morphological characters, such as leaf area (Valluru et al. 2012), ear number, and grain number (Thakur et al. 2010; Li et al. 2017). Limin and Fowler (2000) reported that the cell size of wheat decreased and the young and new leaves became shorter and narrower following cold acclimation. In the present study, the degree of cold injury to the wheat plants and the freezing injury index were all increased from 0.3 to 0.5 with increased low temperature duration at jointing stage, resulting in lower plant height, especially the first and second upper internode length and ear length. Our results are consistent with the report of Li et al. (2017), who found that chilling stress treatment significantly decreased plant height and leaf area in hexaploid wheat. These results indicated that low temperatures affected wheat development mainly by reducing the growth rate, resulting in reduced plant height.

Several cold hardening experiments suggested that endogenous hormones, such as IAA and CKs, may actively participate in the control of plant growth under low-temperature stress (Majláth et al. 2012). Our findings confirmed that there was a strong negative correlation between plant height as well as the upper two internode length and related physiological parameters (Table 3 ), including proline, soluble sugar, $A B A$, and ZR concentrations, while $\mathrm{GA}_{3}$ concentration was positively correlated with these. These data also confirmed that internode elongation was inhibited by higher ABA and ZR levels and lower $\mathrm{GA}_{3}$ level under low temperature. In contrast, the balance among these hormones improved with remedial urea application after low-temperature stress, resulting in greater plant height (Fig. 1). Remedial fertilizer after cold stress at jointing stage mainly promoted the length of the two upper internodes and ear length, ultimately increasing the plant height.

Low temperature not only inhibits wheat growth and development but also results in the loss of grain yield. In Kansas, an additional day of freezing temperature in the spring was associated with a 3.3\% yield reduction over the 1985-2013 period (Tack et al. 2015). In certain regions of Australian wheat belt, a high risk of $\geq 10 \%$ yield losses result from post-heademergence frosts (Zheng et al. 2015). The wheat yield was reduced by $42.5-59.8 \%$ under low temperature $\left(-2^{\circ} \mathrm{C} /-8^{\circ} \mathrm{C}\right.$, 
day/night) from $24 \mathrm{~h}$ to $72 \mathrm{~h}$ at tillering stage in Jiangsu province in China (Li et al. 2017). In the present study, the wheat yield was reduced by $49.42-65.11 \%$ under low temperature $\left(3^{\circ} \mathrm{C} /-4^{\circ} \mathrm{C}\right.$, day/night) from $24 \mathrm{~h}$ to $72 \mathrm{~h}$ at jointing stage. Internode extension and dry matter accumulation were restricted and the spikelet was killed, and thus the grain yield was also decreased due to low temperature during stem elongation (Whaley et al. 2004). Our findings also demonstrated that the reduced number of fertile tillers and grain number per spike were primarily associated with the loss of yield under cold stress at jointing stage.

The cold resistance of wheat was correlated with the levels of expression of TaEXPB7-B in the tillering nodes, which was up-regulated by both low-temperature and ABA (Feng et al. 2019). As a result, young and new tillers were generated rapidly after cold stress at jointing stage (Liu et al. 2019). We also observed this phenomenon in our study. Treatment with remedial urea after low temperature at jointing stage generated more new tillers and enhanced grain yield. Of course, the yield under treatment with remedial urea could not wholly restore and reach the level in natural conditions. The principal component analysis results indicated that grain yield was positively correlated with $\mathrm{GA}_{3}$. The $\mathrm{GA}_{3}$ concentration was higher $23.68 \%-52.65 \%, 16.67-41.4 \%, 25.6-79.8 \%$ with the increased rate of remedial urea than those with T24N0, T48N0 and T72N0, which could benefit from promoting wheat growth, inducing new generated tillers, and internode extension. With increased fertilizer application rate under the same treatment duration, the height of the wheat plants was better restored and the loss of grain yield was lessened.

These findings indicated that remedial fertilizer could increase the growth recovery of the cold-damaged wheat plants and reduce the loss of wheat yield. At jointing stage, considering the recovery effect and nitrogen partial factor productivity, 105 $\mathrm{kg} \mathrm{ha}^{-1}$ urea is recommended for nitrogen amendment when wheat plants are damaged slightly and the freezing injury index is about 0.3 . When the freezing injury index is about $0.5,150 \mathrm{~kg} \mathrm{ha}^{-1}$ urea is suggested. When the freezing injury index is about $0.7,225 \mathrm{~kg} \mathrm{ha}^{-1}$ urea is recommended for recovering wheat growth after severe cold damage. Our findings can offer useful and practical approaches for alleviating the impacts of low temperatures in spring on wheat production. Of course, we need to think about the comprehensive income, including the remedial urea costs, the price of wheat, the negative effect of remedial urea on weak-gluten wheat quality, because the grain protein content will be improved with the remedial urea application after jointing stage.

\section{Conclusion}

Low-temperature damage at jointing stage significantly limited wheat yield and changed the concentrations of osmotic adjustment substances and related hormones, as well as inhibited plant growth, resulting in shorter internode length and plant height and fewer ears and grains per spike. Remedial urea to cold injuried wheat reduced the concentrations of osmotic adjustment substances (proline and soluble sugar) and improved the balance of $A B A, Z R$, and $\mathrm{GA}_{3}$ in the second fully-expanded leaves. Therefore, injuried wheat plants amended with urea application recovered growth more rapidly than those without urea application, resulting in significant increases in the length of the upper two internodes, plant height, new reproductive tiller number, ear number, and wheat grain yield. These advantageous changes became more pronounced with a higher rate of urea application in the same cold duration treatment. Considering the recovery effects and nitrogen partial factor productivity, suitable urea remedial rates were suggested depending on the freezing cold index after cold damage at the wheat jointing stage. These findings provide effective and practical knowledge and approaches to alleviating the impacts of low temperature at jointing stage on wheat production.

\section{Declarations}

Conflicts of Interest: The authors declare no conflicts of interest.

Author Contributions: Conceptualization, C.L. and X.Z.; formal analysis, J.Y. and M.Z.; investigation, J.Y.; Methodology, J.Y. and J.D.; project administration, W.G.; resources, J.D. and X.Z.; writing-original draft, C.L.; writing-review and editing, G.Z.; 
supervision, W.G.

\section{References}

1. Alscher RG, Donahue JL, Cramer CL (1997) Reactive oxygen species and antioxidants: relationships in green cells. Physiol Plant 100:224-233. https://doi.org/10.1111/j.1399-3054.1997.tb04778.x

2. Chen XY, Yao Y, Huo YF, Zhang HQ, Wang S (2020) Trends of four meteorological disasters and the impacts on grain yield in Anhui province. Yangtze Basin Res Environ 29:2285-2295 (In Chinese)

3. Dai F, Huang Y, Zhou M, Zhang G (2009) The influence of cold acclimation on antioxidative enzymes and antioxidants in sensitive and tolerant barley cultivars. Biol Plant 53:257-262. https://doi.org/10.1007/s10535-009-0048-5

4. Dobrev PI, Havlíček L, Vágner M, Malbeck J, Kamínek M (2005) Purification and determination of plant hormones auxin and abscisic acid using solid phase extraction and two-dimensional high performance liquid chromatography. $J$ Chromatogr A 1075:159-166. https://doi.org/10.1016/j.chroma.2005.02.091

5. Dörffling K, Dörffling H, Luck E (2009) Improved frost tolerance and winter hardiness in proline over accumulating winter wheat mutants obtained by in vitro-selection is associated with increased carbohydrate, soluble protein and abscisic acid (ABA) levels. Euphytica 165:545-556. https://doi.org/10.1016/j.chroma.2005.02.091

6. FAO (2020) Responding to the impact of the COVID-19 outbreak on food value chains through efficient logistics. FAO, Rome. https://www.fao.org/policy-support/tools-and-publications/resources-details/en/c/1317663

7. Feng X, Xu YQ, Peng L, Yu XY, Zhao QQ, Feng SS, Zhao ZY, Li FL, Hu BZ (2019) TaEXPB7-B, a ß-expansin gene involved in low-temperature stress and abscisic acid responses, promotes growth and cold resistance in Arabidopsis thaliana. J plant physiol 240:153004. https://doi.org/10.1016/j.jplph.2019.153004

8. Flores PC, Yoon JS, Kim DY, Seo YW (2021) Effect of chilling acclimation on germination and seedlings response to cold in different seed coat colored wheat (Triticum aestivum L.). BMC Plant Biol 21:252-265.

https://doi.org/10.1186/s12870-021-03036-z

9. Frederiks TM, Christopher JT, Sutherl MW, Borrell AK (2015) Post-head-emergence frost in wheat and barley: defining the problem, assessing the damage, and identifying resistance. J Exp Bot 66:3487-3498.

https://doi.org/10.1093/jxb/erv088

10. Fuller MP, Fuller AM, Kaniouras S, Christophers J, Fredericks T (2007) The freezing characteristics of wheat at ear emergence. Eur J Agron 26:435-441. https://doi.org/10.1016/j.eja.2007.01.001

11. Gao Y, Tang JW, Yin GH, Han YL, Huang F, Wang LN, Yu HF, Li NN, Zhang Q, Yang GY et al (2015) Effect of different periods and frequency of late spring coldness on winter wheat yield related traits. J Triticeae crops 35:687-692 (In Chinese). https://doi.org/10.7606/j.issn.1009-1041.2015.05.17

12. Hassan MA, Chen X, Farooq M, Muhammad N, Zhang Y, Xu H, Ke YY, Bruno AK, Zhang LL, Li JC (2021) Cold stress in wheat: Plant acclimation responses and management strategies. Front Plant Sci 12. https:// doi.org/10.3389/fpls.2021.676884

13. Horvath E, Pál M, Szalai G, Páldi E, Janda T (2007) Exogenous 4-hydroxybenzoic acid and salicylic acid modulate the effect of short-term drought and freezing stress on wheat plants. Biol Plant 51:480-487. https://doi.org/10.1007/s10535-007-0101-1

14. Hou MY (2003) The QTL mapping of low temperature germinability and anoxia germination in rice (Oryza aativa L.). Ph D thesis, Nanjing Agricultural University, Nanjing pp. 33-40

15. Hussain HA, Hussain S, Khaliq A, Ashraf U, Anjum SA, Men SN, Wang LC (2018) Chilling and drought stresses in crop plants: implications, cross talk, and potential management opportunities. Front Plant Sci https://doi.org/10.3389/fpls. 201800393 
16. Ji HT, Xiao LJ, Xia YM, Song H, Liu B, Tang L, Cao WX, Zhu Y, Liu LL (2017) Effects of jointing and booting low temperature stresses on grain yield and yield components in wheat. Agr For Meteorol 243:33-42. https://doi.org/10.1016/j.agrformet.2017.04.016

17. Kalapos B, Dobrev P, Nagy T, Vítámvá P, Györgyey J, Kocsy G, Marincs F, Galiba G (2016) Transcript and hormone analyses reveal the involvement of ABA-signalling, hormone crosstalk and genotype-specific biological processes in cold-shock response in wheat. Plant Sci 253:86-97. https://doi.org/10.1016/j.plantsci.2016.09.017

18. Kaplan F, Sung DY, Guy CL (2006) Roles of $\beta$-amylase and starch breakdown during temperatures stress. Physiol Plant 126:120-128. https://doi.org/10.1111/j.1399-3054.2006.00604.x

19. Li CY, Xu W, Liu LW, Lei XW, Yang J, Zhou DD, Zhu XK, Guo WS (2016) Effect of short time low temperature from anther connective stage to anthesis on wheat yield and physiological characteristics. J Triticeae Crops 36:77-85 (in Chinese). https://doi.org/10.7606/j.issn.1009-1041.2016.01.11

20. Li CY, Yang J, Zhang YX, Yao MH, Zhu XK, Guo WS (2017) Retrieval effects of remedial fertilizer after freeze injury on wheat yield and its mechanism at tillering stage. Sci Agric Sin 50:1781-1791 (in Chinese). https://doi.org/10.3864/j.issn.0578-1752.2017.10.004

21. Li PF, Ma BL, Xiong YC, Zhang WY (2017) Morphological and physiological responses of different wheat genotypes to chilling stress: a cue to explain yield loss. J Sci Food Agr 97:4036-4045. https://doi.org/10.1002/jsfa.8271

22. Li XN, Hao CL, Zhong JW, Liu FL, Cai J, Wang X, Zhou Q, Dai TB, Cao WX, Jiang D (2015) Mechano-stimulated modifications in the chlst antioxidant system and proteome changes are associated with cold response in wheat. BMC Plant Biol 15:219-232. https://doi.org/10.1186/s12870-015-0610-6

23. Li XN, Jiang D, Liu FL (2016) Winter soil warming exacerbates the impacts of spring low temperature stress on wheat. J Agron Crop Sci 202:554-563. https://doi.org/10.1111/jac.12177

24. Li XN, Jiang HD, Liu FL, Cai J, Dai TB, Cao WX, Jiang D (2013) Induction of chilling tolerance in wheat during germination by pre-soaking seed with nitric oxide and gibberellin. Plant Growth Regul 71:31-40. https://doi.org/10.1007/s10725-013-9805-8

25. Limin AE, Fowler DB (2000) Morphological and cytological characters associated with low-temperature tolerance in wheat (Triticum aestivum L. em Thell.). Can J Plant Sci 80:687-692. https://doi.org/10.4141/P99-178

26. Liu LL, Xia YM, Liu B, Chang CY, Xiao LJ, Shen J, Tang L, Cao WX Individual and combined effects of jointing and booting low-temperature stress on wheat yield.Eur J Agron.https:// do.org/10.1016/j.eja.2019.125989

27. Livingston DP, Premakumar R, Tallury SP (2006) Carbohydrate partitioning between upper and lower regions of the crown in oat and rye during cold acclimation and freezing. Cryobiology 52:200-208.

https://doi.org/10.1016/j.cryobiol.2005.11.001

28. Luo XL, Zang Y, Sun ZF, Du KM, Song GS (2011) Spatial and temporal distribution of winter wheat frost injury in Huanghuai plain. China Agric Sci Bull 22:45-50 (in Chinese)

29. Majláth I, Szalai G, Soós V, Sebestyén E, Balázs E, Vanková R, Dobrev PI, Tari I, Tandori J, Janda T (2012) Effect of light on the gene expression and hormonal status of winter and spring wheat plants during cold hardening. Physiol Plant 145:296-314. https://doi.org/10.1111/j.1399-3054.2012.01579.x

30. Miao Q, Zhao H, Ma ZQ, Qiu J, Zhu HZ, Wang XC, Fu DP (2007) Technical procedures for wheat variety regional trials. The Agricultural Trade Standard of the P. R.C.. NY/T 1301

31. Neilson KA, Gammulla CG, Mirzaei M, Imin N, Haynes PA (2010) Proteomic analysis of temperature stress in plants. Proteomics 10:828-845. https://doi.org/10.1002/pmic.2009000538

32. Patton AJ, Cunningham SM, Volenec JJ, Reicher ZJ (2007) Differences in freeze tolerance of zoysiagrasses. II. carbohydrates and proline. Crop Sci 47:2170-2181. https://doi.org/10.2135/cropsci2006.12.0784

33. Pěnčík A, Rolčík J, Novák O, Magnus V, Barták P, Buchtík R, Salopek-sondi B, Strnad M (2009) Isolation of novel indole3-acetic acid conjugates by immunoaffinity extraction. Talanta 80:651-655. 
https://doi.org/10.1016/j.talanta.2009.07.043

34. Penfield S (2008) Temperature perception and signal transduction in plants. New Phytol 179:615-628. https://doi.org/10.1111/j.1469-8137.2008.02478.x

35. Sun XC, Hu CX, Tan QL, Liu JS, Liu HG (2009) Effects of molybdenum on expression of cold-responsive genes in abscisic acid (ABA)-dependent and ABA-independent pathways in winter wheat under low-temperature stress. Ann BotLondon 104:345-356. https://doi.org/10.1093/aob/mcp133

36. Tack J, Barkley A, Nalley LL (2015) Effect of warming temperatures on US wheat yields. P Natl Acad Sci USA 22:6931-6936. https://doi.org/10.1073/pnas.1415181112

37. Thakur P, Kumar S, Malik JA, Berger JD, Nayyar H (2010) Cold stress effects on reproductive development in grain crops: an overview. Environ Exp Bot 67:429-443. https://doi.org/10.1016/j.envexpbot.2009.09.004

38. Valitovaa J, Renkova A, Mukhitova F, Dmitrieva S, Beckett RP, Minibayeva FV (2019) Membrane sterols and genes of sterol biosynthesis are involved in the response of Triticum aestivum seedlings to cold stress. Plant Physiol Bioch 142:452-459. https://doi.org/10.1016/j.plaphy.2019.07.026

39. Valluru R, Link J, Claupein W (2012) Consequences of early chilling stress in two Triticum species: plastic responses and adaptive significance. Plant Biol 14:641-651. https://doi.org/10.1111/j.1438-8677.2011.00540.x

40. Vaseva II, Todorova D, Malbeck J, Trávníčková A, Machačkova I (2009) Mild temperature stress modulates cytokinin content and cytokinin oxidase/dehydrogenase activity in young pea plants. Acta Agron Hung 57:33-40. https://doi.org/10.1556/AAgr.57.2009.1.4

41. Wang WL, Wang X, Huang M, Cai J, Zhou Q, Dai TB, Jiang D (2020) Alleviation of field low-temperature stress in winter wheat by exogenous application of salicylic acid. J Plant Growth Regul. https://doi.org/10.1007/s00344-020-10144-x

42. Wang YL, Cui YT, Hu GH, Wang XD, Chen HZ, Shi QH, Xiang J, Zhang YK, Zhu DF, Zhang YP (2018) Reduced bioactive gibberellin content in rice seeds under low temperature leads to decreased sugar consumption and low seed germination rates. Plant Physiol Bioch 133:1-10. https://doi.org/10.1016/j.plaphy.2018.10.020

43. Whaley JM, Kirby EJM, Spink JH, Foulkes MJ, Sparkes DL (2004) Frost damage to winter wheat in the UK: the effect of plant population density. Eur J Agron 21:105-115. https://doi.org/10.1016/S1161-0301(03)00090-X

44. Yang QZ, Zhang ZK, Rao JP, Wang YP, Sun ZY, Ma QS, Dong XQ (2013) Low-temperature conditioning induces chilling tolerance in 'Hayward' kiwifruit by enhancing antioxidant enzyme activity and regulating endogenous hormones levels. J Sci Food Agr 93:3691-3699. https://doi.org/10.1002/jsfa.6195

45. Yu J, Cang J, Lu QW, Fan B, Xu QH, Li WN, Wang XT (2020) ABA enhanced cold tolerance of wheat 'dn1' via increasing ROS scavenging system. Plant Signal Behav 15:e1780403. https://doi.org/10.1080/15592324.2020.1780403

46. Zhang WJ, Wang JQ, Huang ZL, Mi L, Xu KF, Wu JJ, Fan YH, Ma SY, Jiang DG (2019) Effects of low temperature at booting stage on sucrose metabolism and endogenous hormone contents in winter wheat spikelet. Front Plant Sci 10. https://doi.org/10.3389/fpls.2019.00498

47. Zhang ZL, Qu WQ (2003) Experimental guidance of plant physiology. High Education, Beijing, China, pp.127-128 and pp.258-259. (in Chinese)

48. Zheng BY, Chapman SC, Christopher JT, Frederiks TM, Chenu K (2015) Frost trends and their estimated impact on yield in the Australian wheatbelt. J Exp Bot 66:3611-3623. https://doi.org/10.1093/jxb/erv163

49. Zhu HH, Wu YF, Song JQ, Du KM (2018) Analysis to late frost damage for winter wheat based on meteorological factors: taking Henan province as an example. Chin J Agrometeorol 39:59-68 (in Chinese).

https://doi.org/10.3969/j.issn.1000-6362.2018.01.007

\section{Figures}




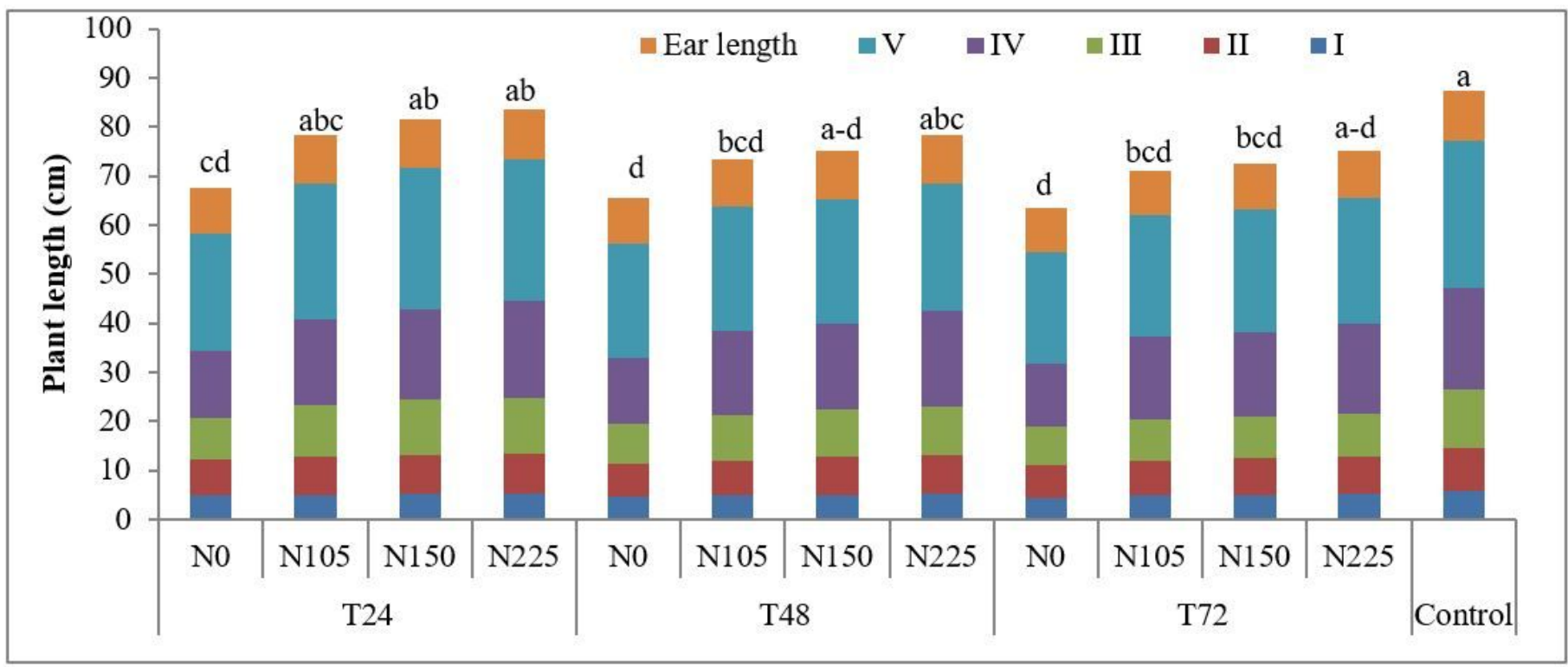

Figure 1

Changes in the length of internode, ear and plant after urea amendment to cold-damaged wheat at jointing stage (20132014 wheat growing season) 


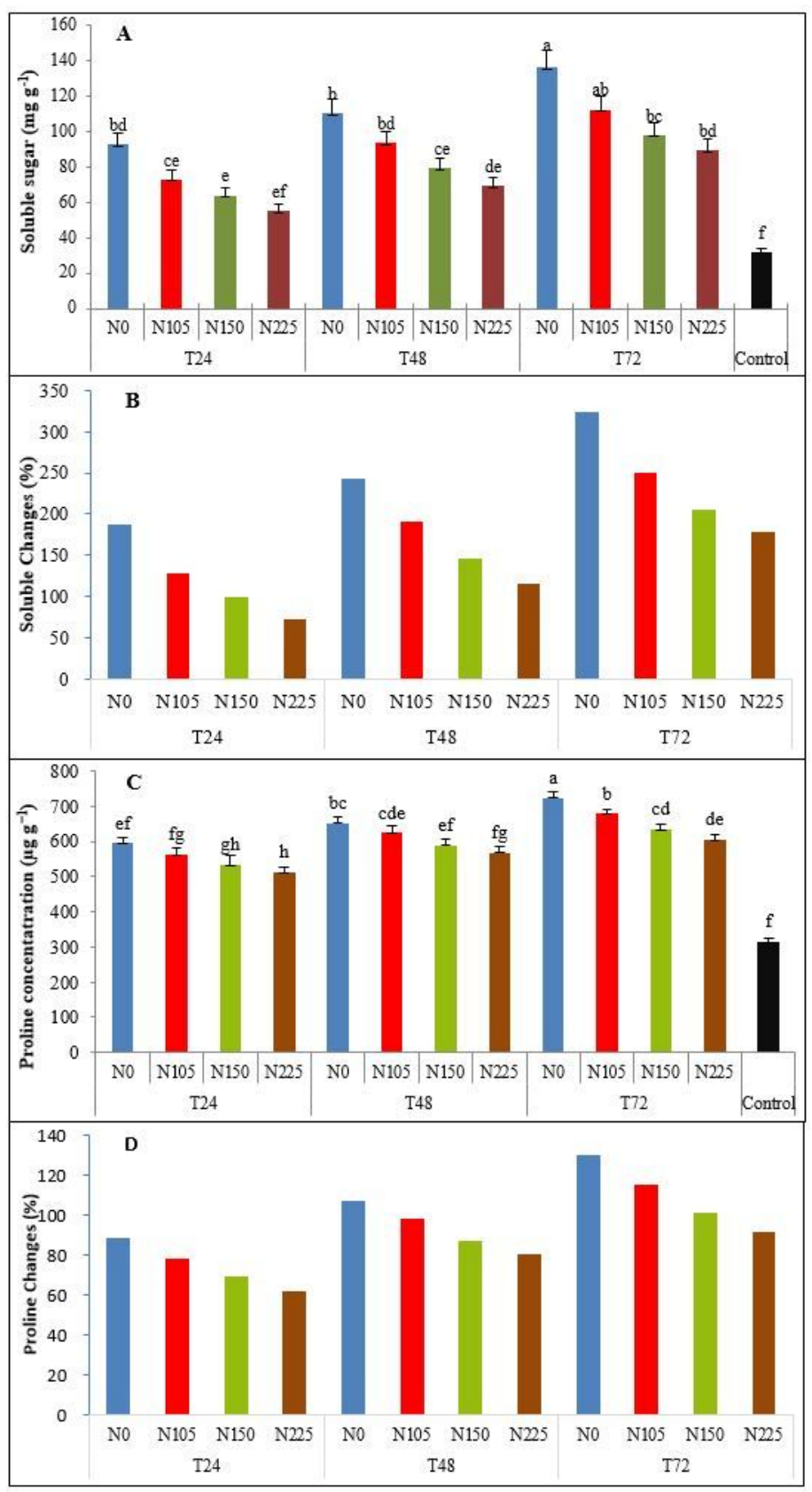

Figure 2

Changes in soluble sugar and proline concentrations in the second leaves from the top on the $10^{\text {th }}$ day after urea amendment to cold-damaged wheat at jointing stage (2013-2014 wheat growing season) 


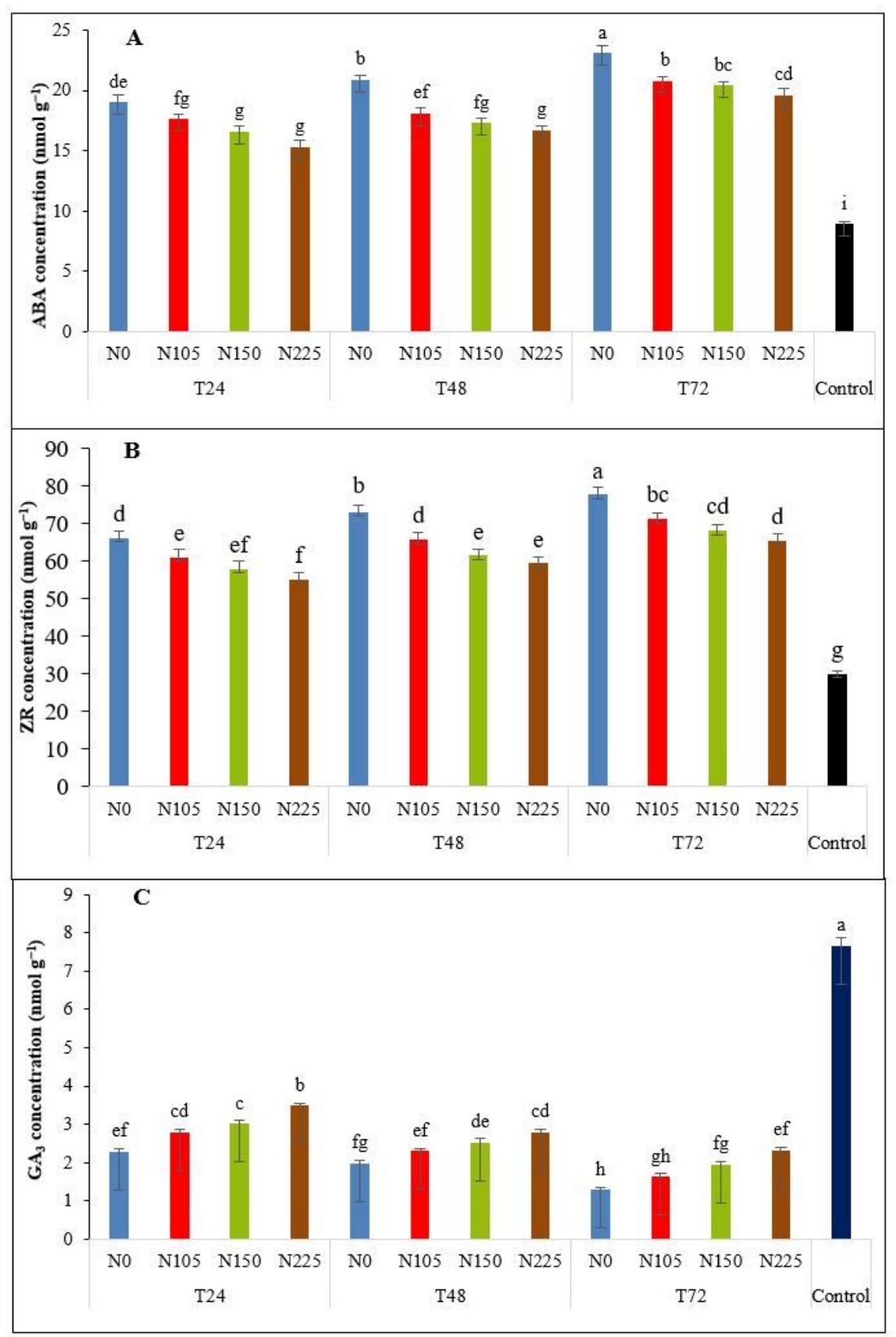

Figure 3

Changes in $A B A(A), Z R(B)$ and $G_{3}(C)$ contents in the second leaf from the top after urea amendment to cold-damaged wheat plants at jointing stage in the 2013-2014 growing season.

ABA, abscisic acid; $\mathrm{GA}_{3}$, gibberellic acid; $\mathrm{ZR}$, zeatin riboside. 